\title{
Charles Darwin University
}

\author{
Glenn Morrison, Raelke Grimmer, Adelle Sefton-Rowston
}

\section{Borderlands: Scoping the publishing landscape for a regional Australian literary journal}

\begin{abstract}
:
This paper surveys Australian literature regarding the publication of literary journals and the qualitative costs and benefits of their production. The survey was undertaken as part of a research project to develop a literary journal for Australia's Northern Territory, which has been without a substantial journal of its own since 2000. As part of the project, the researchers also surveyed public attitudes towards a literary journal, interviewed key industry stakeholders, and commenced business planning for a journal, all framed by the overview of literature. While only the literature review is reported on here, the attitude surveys, interviews, and business planning may form the subject of future papers. Called The Borderlands Project, the research was begun as part of a 2018 strategic arts project jointly funded by Arts NT and Charles Darwin University to develop a literary journal of the Northern Territory in three phases. This paper outlines the purpose of the project and describes preliminary results from the literature survey, including comments on funding, journal format, content, how to address the problem of prosumerism, and future directions for the research.
\end{abstract}

Biographical notes:

Dr Glenn Morrison is a journalist and researcher who lectures at Batchelor Institute of Indigenous Tertiary Education (BIITE) Alice Springs. He is the author of Songlines and fault lines: Epic walks of the red centre (MUP 2017) and Writing home: Walking, literature and belonging in Australia's red centre (MUP Academic 2017).

Raelke Grimmer is a lecturer at Charles Darwin University and a Creative Writing $\mathrm{PhD}$ candidate at Flinders University. Her thesis combines a creative non-fiction work exploring mono-lingualism and multiculturalism in Australia with an exegesis on the role of genre in the writing process. Her work is published in Griffith Review, Westerly and Meniscus.

Dr Adelle Sefton-Rowston is an award-winning essayist, literary scholar and author of Polities and poetics: Race relations and reconciliation in Australian literature, forthcoming for Peter Lang (2019). She is President of the Northern Territory Writers Centre and lecturer in Communications at Charles Darwin University. 
Keywords:

Northern Territory - Literary journal - Publishing - Indigenous - Multicultural Australian literature

\section{Introduction}

This paper reports on a strategic regional arts research project currently underway to develop a literary journal of the Northern Territory (NT) ${ }^{1}$. Called The Borderlands Project, the research was conceived in three broad phases. The first phase aimed to confirm the need for a proposed Northern Territory literary journal, and to research and develop a sustainable business plan (Phase 1 July 2018 - December 2019). With Phase 1 nearing completion at the start of 2019, work has begun on Phase 2, which aims to produce a pilot edition as 'proof of concept' and secure funding for a longerterm publishing endeavour. Phase 3, from 2020, aims to establish an ongoing Northern Territory literary journal, potentially hosted at a major university.

The basic driver for the project is that the Northern Territory has been without a literary journal of its own since 2000, thought to represent a significant shortfall in the cultural and artistic lives of Territorians and other Australians. Since the millennium, public interest in literature has grown substantially, and Indigenous voices have found greater prominence within the Territory and across the nation. Nonetheless, and with so many hopes, dreams and funding now pinned to developing Northern Australia, Territorians remain without the regular forum a literary journal might provide: a place where creative and critical thinkers might evaluate the 'frontier' rhetoric that grand schemes such as 'Develop the North' can entail (Morrison 2015; Bell, Campbell \& Larkin 2014). This is especially important at a time when regional media across Australia is struggling to critically serve their constituencies as the numbers of journalists in newsrooms declines, and digital news rises to prominence in line with global trends. This issue is of special significance nationally given the Northern Territory is the Australian jurisdiction with the highest proportion of Aboriginal and Torres Strait Islander people: 25.5\% at the 2016 census (Australian Bureau of Statistics 2016).

Literary journals are an important component of Australia's literary culture and can foster a range of writerly voices and storytelling. In his brief history of Australian literary journals Tilting at windmills, Phillip Edmonds defines a literary journal as 'a publication that devotes a significant proportion of its pages to original fiction, poetry, essays, creative non-fiction, interviews and reviews, and is a periodical that publishes up to six times a year' (Edmonds 2015: 13). That the Northern Territory should have its own vehicle to broadcast its unique voice nationally (and perhaps beyond) seems only logical. But with alarming regularity, and in patterns mirroring the ups and downs of Australian government arts funding, such journals come and go from the Australian publishing scene, many buckling to the economic realities of producing content that is of only marginal interest to a commercially focussed mainstream ${ }^{2}$. 
Planning a new literary journal for the Northern Territory regional context is therefore a complex undertaking that conflates literary, cultural, and publishing research with business planning, involving many financial uncertainties, all compounded by operating in one of Australia's most remote settings. To build their knowledge about journal publishing, the researchers interviewed Australian journal editors and writers, surveyed attitudes among a potential Territory audience, and tried to evaluate the economics of some broad publishing strategies. Many questions require answers: Is there demand for such a journal? Should it be in print or online? How might it be funded? Exactly how many staff might a journal require? And how might printed copies be distributed across the isolated and diverse reaches of Northern and Central Australia? Would there be national interest in such a publication? International?

While some research questions have been answered, many remain unaddressed, and still more have emerged from the research. This paper does not aim to address them all. Rather, it aims only to present the findings of an introductory survey of the Australian literature on literary journals, the important first step that helped the authors to shape their thinking and set directions for the 2018 research. The main research questions emerging early on included establishing the need for a Northern Territory literary journal or generating alternatives, what Northern Territory publications have come before, and how the Northern Territory might fit into the broader Australian publishing landscape? Another focus was to identify gaps and opportunities in the current Australian publishing sector that might be addressed by a uniquely Territory journal.

By way of background, the paper outlines a brief geography of the Northern Territory, its contextual significance, and the project's beginnings. It then sketches the publishing landscapes of the Northern Territory and Australia and, from the survey of literature, identifies trends that helped to shape the research. Conclusions are drawn regarding the research questions, noting those that still require answers, and identifying some of the ways a Northern Territory literary journal might fill gaps in current Australian publishing. It is hoped the research outlined here and in future papers arising from this project might contribute to a growing knowledge base regarding literary journal production in Australia, and offer help to anyone bravely considering their own literary start-up.

\section{The Northern Territory}

Embracing the iconic tourism, pastoral, and Indigenous geographies of the Top End, Red Centre, Arnhem Land and the Barkly Region, the Northern Territory spans five of Australia's great deserts and covers approximately 1.35 million square kilometres of its central and northern regions. In the Territory's southern two-thirds, the climate is arid or semi-arid, while in the North, or Top End, it is sub-tropical and subject to monsoonal influence.

Sparsely populated by comparison with elsewhere in Australia, much of the Territory is also relatively undeveloped, which has fuelled postcolonial perceptions of the region as an empty 'wilderness'. In reality, almost half of the NT's land area (47\%) is Aboriginal freehold under the Aboriginal Land Rights (Northern Territory) Act 1976, 
and a further five per cent claimable under the Native Title Act (Australian Law Reform Commission nd), all of which straddles widespread pastoralism, an established mining sector, broad-scale geophysical exploration and an emergent gas (by hydraulic fracture) industry.

In 2018, the Northern Territory's population was 246,065, with a median age of about 32 years (Northern Territory Government 2018a). Previously forecast to grow to around 450,000 by 2060 (Northern Territory Government 2015), population growth has instead flattened (Taylor \& Carson 2017). The present populace is concentrated mainly in Darwin $(136,828)$ and Alice Springs $(24,753)$, but also spread across the regional centres of Katherine, Tennant Creek, and Yulara near Uluru (Australian Bureau of Statistics 2016). In addition, there are about 10,000 Indigenous people living remotely on 500 Indigenous homelands, interspersed with pastoralists living and working on stations away from the main centres (Northern Territory Government 2018b).

There are slightly more Territorian men than women, and Aboriginal and Torres Strait Islander people comprise one quarter of the population, a level rising as a result of higher birth rates than for their non-Indigenous neighbours. The Territory hosts a variety of ethnic communities, with almost a quarter $(24.4 \%)$ of the population speaking a language other than English at home; the four most spoken languages after English are Kriol, Djambarrpuyngu, Greek and Tagalog (Australian Bureau of Statistics 2016). Darwin hosts long-standing Greek and Chinese ethnic communities and has strong social and trade links with Indonesia and South East Asia, while Filipino, Indian, New Zealand, and Nepalese communities are growing rapidly in settlements across the Territory. Recently, significant populations of African refugees have been resettled in regional towns such as Alice Springs, where they join a recently booming population of Indian newcomers. Because of its proximity to South East Asia, it is often said that Darwin and the Top End have more in common with Dili and Jakarta than Melbourne or Sydney.

\section{Significance of the Northern Territory context}

A great deal of attention is focussed on the Territory for its contribution to constructions of an Australian 'settler' identity (Morrison 2017a; Dewar 2008, 1996; Carment 2005; McGrath 2004; Powell 1996; Stratton 1989). It should be noted here that the term 'settler' is used to mean non-Indigenous or colonial/European, rather than to invoke the important debate around whether Australia was settled or invaded. In this sense then, John Chesterman and Heather Douglas call the Territory 'the nation's crucible', a place where identities might be forged (2009: 69). Interwoven with its political significance, Northern Territory literature embraces subjects of colonisation, environment and the role of Indigenous peoples (Dewar 1997). The underlying aim, suggests Dewar, is to legitimise non-indigenous settlers' actions during and after colonisation, a literary construction of the Northern Territory being a metaphor for European occupation of Australia.

Implicit in constructions of Australian identity is the 'frontier' metaphor. Considered both a place and an idea, the frontier has been one of 'the most pervasive, evocative 
tropes underlying the production of national identity in Australia' (Davis 2005: 7). In a 2015 doorstop interview, for example, former Australian prime minister Tony Abbot stood on a concrete dam wall near the northern town of Kununurra against a spectacular backdrop of the controversial Ord River scheme to declare 'the North' as the nation's 'next frontier'; a region ripe for exploitation of its natural wonders (Australian Government 2015a) ${ }^{3}$. Harking back to the colonial and exploration eras, frontier representations doggedly persist for the Northern Territory and remain politically and culturally divisive (Morrison 2019, 2017a; Davis \& Rose 2005; Dewar 2008, 1997; Angel 2006; Carment 2005). Only recently have more nuanced literary and media representations of the Northern Territory begun to break down such narrow viewpoints, bringing forward Indigenous and othered voices by exploring notions of hybrid storytelling, most evidently in the arts (Morrison 2019, 2017a, 2017b; Finnane 2018, 2011; Sefton-Rowston 2016).

There is a distinct body of Northern Territory regional literature, often called a literature of the North (though also including the Red Centre), which is characterised by its sense of isolation from key centres, and concern with representations of space, cultural interchange, nation, and sense of place (Mead 2009). Political 'regionalism' in Australia has existed since European colonisation, and regional areas like the Northern Territory have consequently developed less capacity to participate in what Pierre Bourdieu (1993) calls the 'field of cultural production' (Henningsgaard 2009). Despite its isolation, however, the Territory has made and continues to make a significant contribution to Indigenous and settler Australian literatures beyond any anticipated ability for it to do so based on its rather small, isolated, and transient population. From the journals of colonial explorer John McDouall Stuart and early Territory writers such as Ion Idreiss, Ernestine Hill, and Frank Clunes, to awardwinning bestsellers such as Robyn Davidson's Tracks (1980), Bruce Chatwin's The songlines (1987), Alexis Wright's Tracker (2018) and Rod Moss's Hard light of day (2010), the Territory has wrought a well-recognised place in Australian literature ${ }^{4}$.

Less well-recognised have been the Northern Territory's Indigenous stories, including Dreaming and other journey narratives that contain Indigenous law, cultural protocols, and history (Turner 2010; Morrison 2019). Prior to the journals of the colonial explorers, an Indigenous storytelling of Australian and Territory places arose from the many extensive trade, cultural, and ceremonial journeys Aboriginals and Torres Strait Islanders frequently made across them, stories nonetheless ignored in subsequent postcolonial Australia's constructions of a national 'settler' identity. Several authors review Indigenous Australian literature (Shoemaker 1989; Clunies Ross 1986; Healy 1989; Mishra 1988), and Morrison (2019) briefly traces the stand-alone publication of Indigenous stories from the colonial era to the present, noting that since the 1980s, Australian and international publication of Indigenous Australian literature has grown substantially. There is also strong recent growth in the number of Dreaming stories published (Morrison 2019, 2014), fuelled in part by the rapid disappearance of Australian Indigenous languages, estimated at two languages lost per year (Regan \& Troy 2014: 120). Adelle Sefton-Rowston (2019) argues that such reading and writing may share with others the connections Indigenous people have with Australian places. Elsewhere, she argues Indigenous sovereignty might be sought by writing of spiritual 
and ancestral connections with place (Sefton-Rowston 2017). For their part, multicultural and multilingual Territory demographics remain poorly served by a Territory literature, as has long been the case for other Australian jurisdictions (Ommundsen 2018).

\section{Why Borderlands?}

The title of the project was conceived to reflect the growing number of Territory authors and artistic creators isolated from the mainstream of Australian artistic endeavour, but who nonetheless pursue publication and acknowledgment of their work within and beyond the borders of the Northern Territory and for a national readership. It speaks of those who would carve a cultural life at the periphery of an Australian mainstream, sometimes referred to as the edge of an Australian 'real', a mythical place usually represented by the east coast cities of Sydney and Melbourne (Stratton 1989).

Importantly, the idea of the Territory as a borderland may also help to disrupt thinking of it as a frontier: a term widely perceived to convey a place of trouble and turmoil (see Morrison 2019, 2017a). An Australian frontier embodies the dualism of a divide between nature and culture, separating Indigenous and non-Indigenous groups across an 'impermeable' ontological barrier, dividing ancient from modern, primitive from civilised. Conversely, some critics (and this paper) argue that a more permeable boundary pertains, and they reimagine the frontier as more of a contact zone: a place where cultures meet and mingle (Pratt 1991, 2008; Finnane 2018, 2011; Morrison 2017a). In this paper, a borderland references Chicana writer and theorist Gloria Anzaldúa, who writes in Borderlands/La Frontera: The new mestiza that, in a borderland, 'a frontier line that divides may also come to reflect what the two sides have in common' (Anzaldúa 1987: 3).

\section{Literary publishing in the Northern Territory}

Given its small population it could be argued that the Northern Territory boasts a surprisingly vibrant and growing literary scene. Northern Territory Writers Festivals and periodic regional writing events are attracting bigger and more enthusiastic crowds, with a growing cohort of festival-goers from interstate. By 2017, for example, the Northern Territory Writers Festival in Alice Springs had doubled its audience and tripled its box office since 2015 (Fiona Dorrell, pers comm 15 August 2018).

Meanwhile, Territory writers and critics are themselves attracting unprecedented praise, both locally and nationally ${ }^{5}$.

Historically, the effects of regionalism on literature and particularly literary journals have been profound, in that most subscribers to the journals have come from their respective states, with fewer interstate subscribers and even fewer international subscribers (Ommundsen \& Jacklin 2008). It may come as no surprise that, like elsewhere in regional and inland Australia, the Northern Territory has no prominent literary platform of its own. But there were examples in the past. Charles Darwin University (CDU) published the annual literary journal Northern Perspective from 
1979 to 1999. CDU Professor Emeritus of History, David Carment, who sat on the board of Northern Perspective, told Borderlands that 'Northern Perspective was published for some years by Darwin Community College and included articles, short stories and poems, (but) eventually ceased when it lost its Australia Council funding' (Carment, pers comm). A scan of available digital copies of Northern Perspective reveals the final editions were given over to publishing the work of winners and entrants from the annual Northern Territory Literary Awards (now published by Northern Territory Library). As Professor Carment recalls, Northern Perspective was later rebadged Northerly for one edition in 2000, leaving the Territory without a journal of any substance for almost two decades. Professor Carment states that the periodical 'had a good reputation but struggled to achieve a reasonable circulation. This in the end was why the Australia Council stopped funding it and Northern Territory University decided once that occurred to also withdraw support' (pers comm 27 July 2018).

Territory publishers exist, of course, though none publishes a dedicated literary journal, choosing instead to focus on books. The Institute for Aboriginal Development (IAD) Press recently republished Peter Latz's Central Australian classic, Bushfires and bushtucker (2018), for instance. Ptilotus Press, also based in Alice Springs, is consolidating its reputation with a couple of recent major awards for its Inland book series $^{6}$. Ptilotus had briefly floated an online literary magazine for one edition in 2012, called Inland Sea (Leni Shilton, pers comm 4 August 2018). There is an annual Northern Territory Literary Award, modestly published as a collection of finalists' works by the Northern Territory Library, and the magazine Imprint, an annual members-only, limited-edition journal in print for the Northern Territory Writers Centre (NTWC). There are occasional works from NTWC and Northern Territory Library, intermittent and independent zines, occasional academic texts from CDU Press and a rich array of storytelling and non-fiction published by Batchelor Institute Press, primarily from Indigenous Australians, the majority of whom have English as a second or third language. On the digital side, there is SPUN, a Darwin-based organisation using live videography and interview to tell Territory stories. And last but not least Flycatcher, a small-circulation print and online magazine for students of Charles Darwin University.

In a recent essay for Imprint, the inaugural executive director of the Northern Territory Writers Centre, Marian Devitt, called the loss of Northern Perspective 'a major one for the NT literary scene' (2018). In her experience, there were 'plenty of self-published works ... [that] highlighted the determination of NT writers to have their work heard'. Since Northern Perspective and Northerly, however, other publications of Northern Territory writing have nonetheless emerged. For instance, over four years in the 1990s, Devitt acted as a 'northern correspondent' for Overland where she 'raised the lack of state-based opportunities for NT writers in several dispatches' (2018: 12). By comparison, 'Queensland and Western Australia were subsidising state-based publishers to publish their local writers' (ibid). Eventually, in 1998, Overland published a special supplement of Northern Territory writing, which Devitt helped compile and edit. And there have been others since: Cordite featured a number of Territory poets; there was a collaboration on poetry and prose between 
NTU Press and the NTWC; the special edition of the Griffith Review 'Up north: myths, threats and enchantment' (Schultz 2005), and another by Kill Your Darlings for its 2018 NT Showcase. There is even the occasional 'literary' post in online news journal Crikey's blog The Northern Myth.

\section{Australia's literary journals}

As Patrick Allington notes, Australia has 'a number of well-established literary journals' (2016: 54), including Meanjin, Southerly, Overland, Griffith Review, Island, Quadrant and Westerly. There are also the more recent arrivals of Mascara, The Lifted Brow, Kill Your Darlings, Sydney Review of Books (SRB), and others. It could be argued that each state has what might be construed as its 'own' journal, except for the Northern Territory and ACT, as well as South Australia after Wet Ink, once considered the South Australia A literary journal, closed in 2012 for want of funding ${ }^{7}$.

Perusing the list of journals currently published in Australia, however, one can't help but notice the high concentration in Melbourne and Sydney, with exceptions Westerly and Island (Driscoll 2017). The urban emphasis in the sector suggests the market may well be wide open for a strong regional publication, especially when Australian interest in the literary is growing. As Alice Grundy enthusiastically writes in the Sydney Review of Books, the 'recent sprouting of literary journals in Australia [is] proof of the scene's fecundity' (Grundy 2014: para 2). Granted, the five years prior to Grundy's enthusiastic statement had seen massive growth in the number of Australian literary journals, with corresponding growth in 'literary festivals, book clubs, writing groups and salon style events' (ibid: para 1)). Nonetheless, funding has since become scarcer and many would argue that journals now struggle financially and always have. Some argue journals must engage with a younger audience (see, for example, Edmonds 2015; Grundy 2014; Ommundsen \& Jacklin 2008), others that they need to more closely embrace multicultural and Indigenous audiences (Ball 2018; Ommundsen 2018).

But Australia's reportage and critique of its literary journals appears to be mainly qualitative, and lacks depth in important ways that are particularly disappointing for this study, especially on the detail and mechanics of their production. While Allington argues for Australian journals as 'sites of dissent', for example, he notes also an ongoing and seemingly never-ending debate about 'the past, present and future health of Australian literary magazines' (Allington 2016: 54). Yet in the literature there is only scant detail regarding the practicalities of costs of production, staffing levels, readership figures, all presumably also determinants of journal 'health'. And, of course, some details are perhaps purposefully absent for commercial reasons. Also, given this paper is an introductory survey of the literature, a more expansive search might reveal further material. An exception to the finding, for example, is a recent article published by The Lifted Brow, which detailed the recorded costs and personhours required to produce one edition of its print journal (The Lifted Brow 2016). Some meta-data is also published by the Australia Council. Otherwise, the literature examined here comprises a largely qualitative examination of producing literary journals, much of it found in the literary journals themselves. 
Borderlands' research to date would suggest that Australian literary journals are economically unviable, published into a tough and grant-dependent market that is highly concentrated in urban areas, and consumed by a tiny readership made up largely of contributing writers (Davis 2018, 2006; Smith 2017; Driscoll 2017; Edmonds 2015; Annear 2013). And yet, almost defiantly, some journals have survived on their respective drip feeds of government grants and the generosity of philanthropists for quite lengthy periods. For example, Meanjin has been publishing since 1940, Westerly since 1956. Nonetheless, such a fragile industry is shifting uneasily under the combined influences of neo-liberalism, new technologies, and shrinking university and government arts budgets (Edmonds 2015).

Despite their considerable travails, literary journals remain an important part of Australia's literary culture (ibid). In her otherwise dismissive article for The Monthly, even Robyn Annear (2013: para 4) concedes literary journals are a 'hatchery for new talent'. Philip Edmonds suggests more cheerily that literary magazines have 'represented and reflected the mediating role culture has performed in the evolution of contemporary Australia' (2015: 1). At their best, says Allington, literary journals can perform a much-needed role in the Australian conversation, being to 'publish and extol the virtues of complex and messy ideas and conversations' (2016: 55). At the heart of matters, however, remains a fundamental question: How do we fund, manage, and plan for 'publications that are culturally valuable, but economically unviable, even within their own field' (Smith 2017: 174). And on this, at a practical level, the literature is very quiet.

\section{Key trends in Australian literary journal publishing}

Up until the late 1960s, Australian literary journals gave voice to unpopular opinions and were a place where fledgling writers could hone their skills (Edmonds 2015:1). This fits Allington's description of journals as 'sites of dissent', bold champions of a healthy democracy. Literary journals also act as a springboard for emerging talent (Smith 2017; Edmonds 2015; Annear 2013; Ommundsen \& Jacklin 2008), and are perhaps 'more influential than their small circulation would first indicate' (Edmonds 2015: 1).

Recently, however, Australian literary journals have become much more marketaware in the face of a more difficult funding environment, the result of several trends impacting the broader book publishing industry since the 1980s. In 2000, for example, the book industry changed fundamentally after the introduction of Neilsen BookScan, a technology that traces book sales by barcode. The effect was to shift literary measures of success, previously decided by newspaper book reviewers and editors of literary pages, to a dispassionate accounting of sales turnover. Consequently, and evident from their dominance in recent literary awards, small publishers have taken over the publishing of Australian literature from the big publishers, who have become much more closely concerned with profitability and acquiring bestsellers (Davis 2018; 2006; Stinson 2018, 2016; Smith 2017; Edmonds 2015; Bode 2010).

Arguably, however, a literary paradigm has never been profitable (see Allington 2016; Davis, 2018, 2006). Rather, publishing literary journals always depended on subsidies 
from government, or other external non-market support (Smith 2017; Bode 2010; Davis 2006). It must be noted that all publishing sectors have suffered under the rise of the new conservatism, globalisation, and neo-liberalism since the 1980s, as well as the decline of the welfare state, and an increasing focus on the free market as an economic driver. And when digital media arrived, with its more data-based evaluation of market performance, it only 'served to amplify the challenges of the field' (Smith 2017: 67). Consequently, as major book publishers distanced themselves from the literary in favour of more commercial pursuits, literary journals joined small book publishers in becoming what Davis rather bleakly labels the last bastions of the literary realm (2006).

Whatever their political and cultural role, Australian literary journals remain dogged by practicalities: limited staffing, static subscriptions, varying attitudes to digital and/or print, and a regionalism that limits the reach of certain magazines (Ommundsen \& Jacklin 2008). But perhaps this is their fate, as Allington might argue: to remain on the ragged edge of viability, serving a broader political aim. This research nevertheless searches for ways for a start-up literary journal to foster independence from government coffers, perhaps through advertising, philanthropy, corporate sponsorship, crowd funding or other means. And it is with this in mind that the method brings its goals to the literature, looking for clues, the results summarised below under a number of broad themes that were identified during the literature search.

\section{Does the Northern Territory need a journal of its own?}

In the minds of Territory writers and other creative artists, there is a clear need for a Northern Territory literary journal to showcase their work and broadcast Territory ideas and experiences to a wider audience. And there is a cogent argument that such an endeavour would be in the national interest. The lack of a Northern Territory literary journal represents a disadvantage for strategists and planners, for example, domestically and globally, who may be interested in the people, places, and politics of Australia's North and Centre. For these are culturally and politically prominent regions, unique postcolonial geographies emerging as pivotal in the future of the nation and the broader South East Asian region (Australian Government 2015b). A Territory journal would speak to constructions of national identity, but in a voice that is diverse and inclusive, presented in multiple formats, helping to nuance the region's persistent representation as a frontier. Or so the argument might go.

Such a direction may well serve to establish a unique Territory voice, something that is clearly emphasised by current Australian editors as key to a journal's success and regarding a journal's purpose. For exactly what literary journal editors now choose to publish varies profoundly, and seems increasingly to reflect a desire to find a point of difference in the market (Stinson 2018). This includes a role as arbiters of cultural debate and building a community of literary talent in an economically challenged and competitive market (Smith 2017: 81-2). Borderlands has been interested in providing an Indigenous, multicultural and multi-lingual storytelling voice alongside nonIndigenous voices, by widening the definition of literary writing to storytelling. 
Furthermore, digital technologies are rapidly shifting the boundaries of literary regionalism, which, in the absence of a Territory journal, is only likely to reinforce existing stereotypes of the North and Centre by repeating representations constructed by visiting outsiders (Morrison 2017a). Without a prominent and dedicated journal of their own, then, Northern Territory writers remain unable to readily represent their own context. With their own journal, however, Territorians might stand a chance of providing insider balance to the Territory's representation.

But whether there is an audience for such a journal, and whether its benefits can outweigh the costs (if indeed this is a realistic aim), are separate and more complex questions. And it is these questions the authors now wrestle with as part of their draft business plan. Importantly, the style of question also begs its null-hypotheses: that a journal may not actually be required. One argument in support of a Borderlands nullhypotheses is a past history of Northern Territory special editions by older, more established interstate journals featuring Territory writers. Perhaps Territory writers could more rigorously prosecute their case to such journals, seek to form an interstate partnership for a feature edition with one or another of the already funded publications? Perhaps. But the risk is that a uniquely Territory voice, one fashioned and shaped by Territorians themselves, may be lost in the process. Also, the research counts only three such special editions in the past two decades, which may not be sufficient. It is hoped the answer to this question will emerge from an analysis of the 2018 stakeholder interviews, still to be completed.

\section{The decline of global media}

In a 2009 blog for Meanjin, James Bradley argues for the value of high-quality blogging and interactivity, reasoning that 'as the newspapers stumble dinosaur-like towards their inevitable oblivion, the question of where the Australian cultural and literary conversation will occur is sharpening' (2009: para 8). Bradley points to a unique opportunity for literary journals: to review, critique, and promote the literary. SRB might be considered an outstanding role model, Meanjin's 'Spike' another. But the deficit is not just in arts reportage and criticism. The Finkelstein report of 2012 notes many regional newspapers in Australia have few resources, and therefore a limited capacity to cover local issues in any depth (Finkelstein 2012; see also Berg 2012; Waller, Kristy \& Ricketson 2014). In the Northern Territory the lack of a serious press is particularly acute. For example, a federal push for large-scale development of the North threatens to repeat the mistakes of Australia's developmental past, with Indigenous people marginalised in the process (Kerins 2015). Plans are based on a government white paper that fails to account for climate change and other environmental constraints, such as water and soils (Turton 2015). The push to grow the North comes as news services globally are suffering serious decline caused by digital disruption of the media industry (Park, Fisher, Fuller \& Lee 2018; Elliot 2017). The challenge has left many regional newsrooms ill-equipped to unpack such complex politics for readers (Morrison 2018; Millington, Martin \& Webber 2018). The result is that Territorians remain without a serious regular forum 
where their writers might evaluate and critique their future. This paper would argue that such a deficit might be met in a Northern Territory literary journal.

\section{Countering prosumerism}

Perhaps the most significant challenge to the sustainability of literary journals is the question of whether a literary journal serves its writers or its readers. Most editors think their journal serves readers. Meanwhile, audience analyses continue to prove differently, suggesting many journals are only funded to publish writers. These writers, Smith's research suggests, are rising in number mainly due to the growth of a university-led 'creative writing industry' (2017). Smith cites this 'shadow economy' as a key causal factor distorting the economics of literary journals. Her conclusion is that writers have become the most important stakeholder for the industry, a situation characteristic of 'prosumerism', when those who consume the journals are also involved in producing them, including writers, editors, publishers, writing students, or members of writers centres' (Stinson 2016). The situation is further complicated by writers who do not like buying literary journals (Annear 2013), as well as editors and publishers who mistake the writing community for their potential market (Indyk 2011). There have been widespread efforts to convert writers to readers by offering content attuned to writers' needs and tastes (Smith (2017: 86). Tasmania's Island magazine, for example, stipulates that any writer who is accepted for publication will have the journal subscription cost deducted from their publication fee (Smith 2017: 86). Other techniques include discounts on competition entry fees and prioritising submissions from subscribers. But appealing mainly to writers risks effectively reducing audience appeal by disenfranchising those who are not writers, but who may well still be readers.

Branding a journal with editorial attitude can sometimes make a difference to audience appeal. Taking a clear stance or campaigning on pressing issues can appeal to readers while shoring up finances. Research from Smith (2017) and experience from The Lifted Brow and US journal McSweeney's suggests promoting the idea that buying a copy of the journal is an anti-establishment act of protest, while at the same time shoring up the journal's commercial imperative. Of course, it may be that literary journals have no place striving for commercial viability, that their interests might best be served on the periphery, as sites of dissent (see Allington 2016). But if a journal can reach beyond writers-as-readers to find new audiences, then the economics of its production may run more smoothly.

\section{Print, digital or both}

An important early question is whether a journal should be print or digital. Examples of both abound in the market, and advice from the literature is mixed. Australia launched the world's first ever digital journal with Jacket in 1996, yet print is still favoured by the industry for its appeal to both funders and subscribers (Smith 2017: 71; Menzies-Pike 2017a, 2017b). Conversely, there is little evidence in the literature of a will to question the preference for print by using evidence (if it exists) to say how 
or why digital might do better. Similarly, there is no discussion of whether certain formats suit particular types of storytelling but not others. The result is an apparent inconsistency in decision making, which makes for a rich diversity of offerings. Take the case of editor Catriona Menzies-Pike, who recently declared SRB would never be seen in print (2017a, 2017b), allowing for their publication of a 'best-of-digital' collection of essays in print called Australian Face (2017). Nonetheless, compare Menzies-Pike's decision with the actions of the similarly successful The Lifted Brow, which uses both formats, yet doubled down on its print edition, moving to a more book-like, full colour format because readers and funding bodies enjoy the printed object (see Smith 2017; Menzies-Pike 2017a, 2017b). Meanwhile, news media and overseas publishers are being strongly urged to embrace change and digital technology in order to survive the recent disruption to media (see Critchley 2018).

A shift in emphasis from traditional writing forms to a broader range of storytelling could well be better supported by digital than print. Digital literature might be envisaged as a modern expression of the ancient art of storytelling that can take many forms with text, sound, audio, image, video, or a combination of all of these (multimedia) up for grabs. The challenge becomes how to match the means of telling a story to the story to be told. The approach has delivered some stunning storytelling results in the field of journalism, exemplified in the New York Times' 'Snowfall' and Guardian's 'Firestorm'. Indeed, for non-fiction there is scope to use journalism's nonlinear storytelling techniques now used routinely for multimedia longform and features writing (for example, see Kreuger 2017). Also, new technology may help make the story vetting process easier. For example, US site Storycenter has its own 'easy-to-use storytelling recording station and app', which may mean that evaluating which medium best suits a particular story may no longer be a painstaking or timeconsuming task.

In literary journals, however, it is possible such innovations are being held back by an industry-wide romance with print, despite print's considerable costs compared with digital publishing. That the industry imparts intrinsic value to print appears to be a hangover from an earlier era of publishing, but one that nonetheless offers real (haptic) value to some in the digital age. Rather than print being inevitably replaced by digital, Smith's research concludes that print is 'deployed by editors to communicate literary value, power, and a sense of community, all of which play a role in securing the longevity or survival of their publications' (Smith 2017: 165). The popular emphasis on print is the result of a number of factors, writes Smith, including a general unwillingness for readers to pay for digital content coupled with an expectation that the internet should be free, and that subscribers prefer to receive something tangible for their money, a hard copy of a journal being highly regarded as an artefact in its own right. Further, a print journal is more likely to satisfy the requirements of funding bodies, with government funding guidelines geared towards traditional business models like print, not experimentation. Also, many editors are from an older publishing demographic and enjoy print because it provides a physical symbol of their personal achievement. There is, finally, a pervading mythology or mystique about writers' work being more valued in print than in digital form, that print possesses an 'aura' of literary value (Smith 2017: 86). 


\section{Funding}

Evidence and opinions as to the best way to fund a literary journal vary markedly. The literature is also voluminous, and may well form the basis of a separate paper. Most authors can at least agree that the economic situation for a literary journal is precarious. One example is the long-running literary journal Meanjin (originally Meanjin Papers), started in 1940 in Brisbane under journalist Clem Christesen, but homed in Melbourne since 1944. The magazine is widely recognised as Australia's premier literary magazine (Armstrong 2016), even a 'journal of record' (Smith 2017: 71). Meanjin had been printing editions (and recently posting them) for 75 years when the Australian Government made the decision to slash \$96,000 (30\%) from its heavily subsidised operating costs in 2016. The journal almost folded, with editor Jonathon Green noting at the time that it would be difficult to pay contributors, who, over the years, had included luminaries such as Patrick White, Manning Clarke, Dorothy Hewitt, John Paul Sartre, and Judith Wright (Armstrong 2016; Spicer 2016). Recently, after raising its author rates during 2018 upon receiving $\$ 45,000$ from the funding agency, Meanjin lost all Australia Council funding for 2019: Green grimly tweeted he was 'Not sure we now have any option other than to lower those rates' (Green 2019, Jan 14).

While journals have struggled financially throughout Australian history, universitybased journals may have fared better than others (Edmonds 2015). Conversely, Spahr (2018) and Broinowski (2016) argue that universities, literary theory, and creativewriting courses may well be bureaucratising the writing they produce and should therefore be closely monitored. Still, external funding and security of tenure remain a part of all journals' business models (Ommundsen \& Jacklin 2008). And, as Australian government grants have diminished, there has been more and more interest in philanthropy, often identified as a key funding opportunity for journals, with corporate philanthropy apparently 'thriving' (Scaife et al 2016). Overseas audiences and markets are also a possibility, but surprisingly little examined by the industry in an age when the first strategic goal of the Australia Council is to ensure that 'Australian arts are without borders' and when digital ecologies so directly support their exploitation (Byrne 2018). On specific costs, the aforementioned article in The Lifted Brow (2016) suggests a ballpark figure of $\$ 33,325$ to produce one issue of the journal, in addition to free labour provided by volunteers. Their projected revenue came in at $\$ 26,900$, with the shortfall covered by Creative Victoria and Australia Council grants (The Lifted Brow 2016). A report by Books \& Publishing summarises the figures from the Australia Council's first grant round for 2018, revealing that thirty-four writers and literary organisations were awarded a total of $\$ 780,337$, with nineteen writers and groups receiving arts projects funding, worth up to $\$ 50,000$ (Byrne 2018). Further investigations are required, but it would appear that any Australian literary journal requires a core of grant funding bolstered by philanthropic funding along with lesser degrees of subscription, crowd-funding, advertising and corporate sponsorship. 


\section{Indigenous writing and storytelling}

There is an emerging generation of Australian Indigenous voices who seek spaces in which to publish, or the funding to create them. As emerging Indigenous writer Timmah Ball argues, the rise in Indigenous writers and writing owes thanks to awards, and publishing and mentoring opportunities, including the David Unaipon Award, and publishers such as Magabala Books (2018). There are also fellowships, including the State Library of Queensland's Black\&Write! which pairs an emerging Indigenous writer with an Indigenous editor. Some publishers are creating opportunities and partnerships; for instance, Overland partners with University of Melbourne on the Nakata Brophy Short Fiction and Poetry Prize for Young Indigenous writers (\$5000); Text Publishing's Boundless is in partnership with Writing NSW, and The Monthly has partnered with Indigenous X, a media company founded by Luke Pearson in 2013, on a new mentorship for Indigenous critics. Significantly, Ball cites a number of prominent and emerging Indigenous authors breaking traditional literary boundaries using Indigenous-centred paradigms. $\mathrm{He}$ suggests that cultural criticism be framed around Indigenous rather than Western values, for example in the Yirramboi's Blak Critics program. The argument has profound implications for partnering non-Indigenous writing projects with Indigenous groups, framing Indigenous writing and criticism, and any non-Indigenous criticism of Indigenous writing.

Telling Indigenous and hybrid stories also suggests widening the definition of the literary journal to embrace storytelling, including photo-essays, paintings (as storytelling) and their interpretation, oral storytelling, and videos. For example, Eastern Arrernte artist and NT Writers Centre director Pat Ansell-Dodds told Borderlands that it may be better for some Indigenous storytellers to paint their stories, or tell them (orally), rather than write them down (Ansell-Dodds, pers comm July 2018). Of course, many Indigenous people will want to write, others may be interested in having a mentor help them write down their story (in English or a traditional language). Such assisted storytelling might involve ethnography or the provision of mentoring and editorial advice. Having the largest percentage Indigenous population of any Australian jurisdiction may well make the Territory uniquely positioned to speak from Indigenous perspectives. However, such efforts must be mindful of Indigenous-centred values, and providing Indigenous mentors and editorial staff. The aforementioned storytelling approach to a Territory journal may better frame Indigenous perspectives and facilitate Indigenous partnering. This fits with endeavours already underway by SPUN and Northern Territory Archives.

\section{Multilingual and multicultural voices}

In an interview at the tenth anniversary of her book, Carpentaria, Northern Territory Indigenous author Alexis Wright said: 'The translation of literature is an incredible thing because it helps to break down the barriers of language and distance, and creates communication, instead of silence' (qtd in Byrne 2018). Despite such sentiments, little space in Australian literary journals is given over to multilingual literatures, reflecting that it is little recognised as a part of Australian literature. As Jacklin writes, 
much of Australia's multilingual literatures remain hidden, published only in a language other than English in community language magazines (2012).

Even so, there are examples of Australian literary journals that have catered to multilingual Australian writing. In an essay for Southerly, Jacklin (2012) analysed three multilingual Australian publications from the mid to late 1900s: The muses' magazine (1927-1929), Ambitious friends (1994-2001), and Integration: The magazine for Vietnamese and multicultural issues (1993-2003). Another publication was Outriders: A journal of multicultural Australian literature (1984-1996). While not strictly a multilingual publication, as the journal published mostly English writing including translations from other languages, the journal prioritised multicultural literature.

There have also been one-off projects that have supported multilingual Australian literatures. A 2010 anthology collaboration between NTWC and IAD Press included Indigenous Australian writing in Indigenous languages and English. In addition, a project out of Express Media, Dialect, worked with refugees to write and publish narratives about their experiences in Australia (Muscat 2014). One section in Dialect included micro-stories in English and the language of the writer. In addition, Treasure Language Storytelling and the Multilingual Poetry Slam are two oral storytelling events that advocate for multilingual Australian literatures. Other Australian literary journals, including Mascara Literary Journal, Meanjin, Southerly and The Lifted Brow have released translation editions or published works in translation over the past ten years. Yet the translation editions of both Meanjin (2005) and Southerly (2010) focused on Australian translations of writing from overseas, rather than Australian multilingual writing.

Generally speaking, multilingual writing in contemporary Australian literary journals is relegated to special, themed issues of journals, rather than being included as a key component of each issue. Furthermore, Australian literary journals do not cater for oral storytelling, which is a core strategy for including multilingual literatures within Australian literature. Yet publishing multilingual voices could well be a key opportunity for literary journals. As Ommundsen argues, a cache of previously unheard stories recently unearthed is helping to characterise an immigrant and othered experience of Australia (2018). Ommundsen's analysis focuses on Spanish, Arabic, Vietnamese, and Chinese stories. But she warns 'the archives of Australian writing in languages other than English are fragile and easily lost as authors and editors die and copies of journals and books are lost or discarded' (ibid).

\section{Literary enabling}

Assisted writing and storytelling are also discussed, whereby some journals help fledgling or inexperienced writers to write or tell their stories. Enabling novice writers speaks directly to this, the idea being to reach beyond prosumerism through assisted storytelling, where those with a story to tell are helped to tell it. This may help build audience as well as provide paid work for writers in facilitation or ethnography, perhaps even fostering partnerships with organisations already involved in storytelling. 
Of interest also is the idea of an 'affective network' designed to make writers and readers invested in the success of a journal. Smith (2017: 90-4) cites US-based McSweeney's and Australia's The Lifted Brow as cases in point, along with Kill Your Darlings and Going Down Swinging. Key points are materiality, aesthetics, an emphasis on community, and emphasising the personalities behind the publication. For McSweeney's, and The Lifted Brow, meaningfulness of literature is amplified by the affective qualities of print, and there is a transparency revealed to the reader (an old newspaper tactic) through emphases on the ethics of environmental sustainability in the product (for example, the paper chosen), and always paying contributors. Both journals adopt a strong and defining editorial stance or 'attitude': McSweeney's makes a human connection to audiences through this transparency and what Smith describes as an 'anti-market discourse' (2017: 92, presumably one which acts as if it cares little for market forces, while keeping a weather eye to its own profitability. The Lifted Brow acts similarly by publishing the works of marginalised groups and on taboo subjects. In both cases, the stance is at once anti-market and commercial, an irony not lost on its editors presumably.

\section{Conclusions}

This paper reports on the Borderlands research project that aims to establish whether or not the Northern Territory needs its own literary journal, something Territorians have not had since 2000. The paper has focused mainly on a review of Australian literature regarding the production of literary journals. The review informed later phases of the Borderlands Project, including an audience survey, stakeholder interviews, and business planning, material which may form the basis for future papers. Not explored in detail for this paper is the overseas experience. And one aspect of this stands out as potentially pivotal, which is the close relationship (compared with other Australian jurisdictions) between the Northern Territory and Indonesia, Asia, China, and, in particular, major centres of literary activity such as Singapore, Hong Kong, Jakarta, and Bejing. With geographic proximity and significant intercultural ties to several groups within the Territory, literary activity in these nearby regions and centres could well be a significant factor.

Based only on the literature review, it is not certain whether the interests of Territory writers would best be served by a uniquely Territory journal, or by partnering with existing journals interstate. It is hoped this becomes clear as the research proceeds. Nonetheless, the literature survey identified a range of themes of interest to literary start-ups. These include that Australian literature itself is largely qualitative in its analysis of journal production, suggesting the need for more quantitative research. Australian literary journals are characterised by a rising prosumerism, due in part to the growth in a university-based creative-writing 'industry'. Many Australian literary journals do not appear to be fully embracing the digital world, despite its potentially lower costs, but rather continue to entertain a romance with print, which remains highly valued for its haptic qualities and sense of literary worth. Conversely, there are unique cultural and even economic opportunities for an Australian literary sector that chooses to embrace Indigenous, multi-lingual, and multicultural voices, perhaps best 
expressed in a digital realm. Finally, and while further investigations are still required, it would appear that any Australian literary journal requires a core of government grant funding bolstered by philanthropic funds, along with lesser degrees of subscription, crowd-funding, advertising, and corporate sponsorship.

\section{Notes}

1. Phase 1 of the research was conducted under a Northern Territory Government strategic grant from Arts NT along with seed funding from Charles Darwin University.

2. Early in 2019, several prominent journals lost or missed out on major funding from government funding agency the Australia Council. The Lifted Brow announced on its blog that it had lost Australia Council funding for 2019, as did Meanjin via a tweet from editor Jonathon Green (Green J 2019 Jan 14). Popular Tasmanian journal Island also missed out (islandmagtas 2019 Jan 15) along with a number of other journals.

3. The North is defined by a 'Brisbane Line', so called because soon after the bombing of Darwin by Japanese forces in 1942, those living north of Brisbane became convinced a latitudinal line had been drawn through the city and across the nation, leaving them in an area not to be defended (Shultz 2005: 8).

4. For the interested reader, a discrete North Australian literary genre has been variously compiled and analysed by Trevor James (1984), David Headon (1991), Mickey Dewar (1996, 1997, 2008), Anita Angel (2006), Morrison (2017a) and Sefton-Rowston (2019).

5. Mary Anne Butler's play Broken won the 2016 Victorian Prize for Literature, the Victorian Premier's Literary Award for Drama and the 2014 Northern Territory Literary Award. It was shortlisted for a 2016 AWGIE, 2016 Nick Enright Award and 2014 Griffin Award. Alexis Wright's biography of Tracker Tilmouth Tracker (Giramondo 2018) won the 2018 Stella Prize.

6. Ptilotus Press won the Small Press Network's (SPN) Most Underrated Book Award (MUBA) in November 2018 for Living in hope (Ptilotus Press 2018), by Frank Byrne with Gerard Waterford and Francis Coughlan. The same book had won Best Non-fiction Award at the 2018 Territory Read Awards in Darwin during July.

7. There is also Tulpa magazine, an SA Arts online magazine publishing poetry, fiction and short stories.

\section{Works cited}

Allington, P 2016 'Australian literary magazines as sites of dissent', LOGOS 27,1, 53-62 doi $10.1163 / 1878-4712-11112098$

Angel, A 2006, 'The voice from above: A north Australian literary tradition', Journal of Northern Territory History 17, 55-64

Annear, R 2013 'Puzzling the purpose of Australian literary magazines: Unripe fruit', The Monthly, at http://www.themonthly.com.au/issue/2013/october/1380549600/robyn-annear/puzzling-purposeaustralian-literary-magazines (accessed 12 March 2013)

Anzaldúa, G 1987 Borderlands: The new mestiza = La Frontera, Spinsters/Aunt Lute

Armstrong, J 2016 'The Meanjin funding cuts: a graceless coup?', The Conversation 16 May, at https://theconversation.com/the-meanjin-funding-cuts-a-graceless-coup-59455 (accessed 6 August 2018) 
Australian Government 2015a 'Joint doorstop interview, Kununurra', PM Transcripts: Transcripts from the Prime Ministers of Australia, at http://pmtranscripts.pmc.gov.au/release/transcript-24728 (accessed 16 January 2019)

Australian Government 2015b Our North, our future: White Paper on developing Northern Australia, Department of Industry, Innovation and Science, June, at https://www.industry.gov.au/data-andpublications/our-north-our-future-white-paper-on-developing-northern-australia (accessed 18 January 2019)

Australian Law Reform Commission nd 'Land rights and native title in the states and territories' at https://www.alrc.gov.au/publications/land-rights-and-native-title-states-and-territories\#_ftn53 (accessed 18 July 2018)

Australian Bureau of Statistics 2016 '2016 Census QuickStats', at http://quickstats.censusdata.abs.gov.au/census_services/getproduct/census/2016/quickstat/7?opendocu ment\#cultural (accessed 14 August 2018)

Ball, T 2018 'Indigenous voices have never been more important to Australian literature', The Guardian 23 June, at https://www.theguardian.com/books/2018/jun/23/indigenous-voices-have-neverbeen-more-important-to-australian-literature (accessed 7 July 2018)

Bell, S, A Campbell and S Larkin 2014 'Northern Australia, the sequel: remaking an old policy classic', The Conversation. 5 March at http://theconversation.com/northern-australia-the-sequelremaking-an-old-policy-classic-23833 (accessed 25 February 2019)

Berg, C 2012 'The Finkelstein report into media and media regulation: Licensing, censorship and accountability', Institute of Public Affairs Briefing Paper, at https://ipa.org.au/wpcontent/uploads/archive/1331177474_document_070312_-_finkelstein_briefing_paper_1.pdf (accessed 11 February 2019)

Bode, K 2010 'Publishing and Australian literature: Crisis, decline or transformation?', Cultural Studies Review 16 (2) September, 24-48, at http://epress.lib.uts.edu.au/journals/index.php/csrj/index (accessed 20 July 2018)

Bourdieu, P 1993 The field of cultural production: Essays on art and literature Columbia: Columbia University Press

Bradley, J 2009 'Meanjin: signal from noise?', City of Tongues Blog 28 May, at https://cityoftongues.com/2009/05/28/meanjin-signal-from-noise/ (accessed 3 August 2018)

Broinowski, A 2016 'Creative writing, theoretically' Overland 27 Oct, at https://overland.org.au/2016/10/creative-writing-theoretically/ (accessed ??)

Byrne, W 2018 'Australia Council's Wenona Byrne talks literary trends', Copyright Agency January 23, at https://www.copyright.com.au/2018/01/australia-councils-wenona-byrne-talks-literary-trends/ (accessed 29 Aug 2018)

Carment, D 2005 'Unfurling the flag: Historians, identity and politics in Australia and the Northern Territory', Journal of Northern Territory History 16, 29-35

Chatwin, B 1987 The songlines, London: Jonathon Cape

Chesterman, J and H Douglas 2009 'Law on Australia's Northern Frontier: The fall and rise of race' Canadian Journal of Law and Society 24 (1), 69-83.

Clunies-Ross, M 1986 'Australian Aboriginal oral traditions: 1. A history of research and scholarship', Oral Tradition 1 (2), 231-71

Critchley, A 2018 “'Go out and see the world”: Mexico's publishers urged to accelerate innovation', Publishing Perspectives 27 July, at https://publishingperspectives.com/2018/07/go-out-and-see-theworld-mexico-publishers-urged-to-accelerate-innovation/ (accessed 3 August 2018)

Davidson, R 1980 Tracks, London: Jonathon Cape

Davis, M 2006 'The decline of the literary paradigm in Australian publishing', Ten Years, HEAT 12, $91-108$ 
Davis, M 2018 'Who needs cultural gatekeepers anyway? Australian literary culture and its post-digital anxieties', Sydney Review of Books 17 July, at https://sydneyreviewofbooks.com/who-needs-culturalgatekeepers-anyway/ (accessed 20 July 2018)

Davis, R 2005 'Introduction: Transforming the Frontier in Contemporary Australia', in R Davis and D B Rose (eds) Dislocating the frontier: Essaying the mystique of the outback, Canberra: Australian National University Press, 7-22

Davis R and DB Rose (eds) 2005 Dislocating the frontier: Essaying the mystique of the outback, Canberra: ANU Press

Devitt, M 2018 'The early years of the NT Writers' Centre' Imprint: The Northern Territory Writers Centre Journal, December, 10-12.

Dewar, M 1996 'Frontier theory and the construction of meaning in Northern Territory writing [Paper at Australian Historical Association Conference (1991: Darwin NT]', Journal of Northern Territory History 7, 15-24

Dewar, M 1997 In search of the Never Never: Looking for Australia in Northern Territory writing, Darwin: Northern Territory University Press

Dewar, M 2008 'Literary constructions' in The cultural values of the central ranges: A preliminary report, Darwin: NRETAS, Northern Territory

Driscoll, B 2017 'Contemporary Australian literature', Oxford research encyclopaedia of Literature, at http://literature.oxfordre.com/view/10.1093/acrefore/9780190201098.001.0001/acrefore9780190201098-e-153 (accessed 27 February 2019)

Edmonds, P 2015 Tilting at windmills: The literary magazine in Australia 1968-2012, Adelaide: University of Adelaide Press

Elliot, S 2017 'The state of the media and science reporting in Australia', Australian Science Media Centre, at https://omc.uq.edu.au/files/1720/The-state-of-the-media-and-science-reporting-inAustralia.pdf (accessed 29 Aug 2018)

Finkelstein, M 2012 Report of the independent inquiry into media and media regulation [electronic resource] / by R. Finkelstein assisted by M. Ricketson. Canberra : Dept. of Broadband, Communications and the Digital Economy, at http://www.abc.net.au/mediawatch/transcripts/1205_finkelstein.pdf (accessed 27 January 2019)

Finnane, K 2011 'Treading the fault-line of inter-cultural relations in Alice Springs', Artlink 31, 3, 72 73

Finnane, K 2018 'Meeting in the space between us', International Journal of Applied Psychoanalytical Studies 15, 76-90, at https://doi.org/10.1002/aps.1569 (accessed 3 August 2018)

Green, J 2019 Jan 14 ‘Sad to report @meanjin will get no 2019 Australia Council funding. We were given a grant of $\$ 45 \mathrm{k}$ in 2018 and used it to increase writer payments. We pay for every word we publish. Not sure we now have any option other than to lower those rates. Help a writer: buy a magazine :)' [Twitter Post], at https://twitter.com/GreenJ/status/1084620998421274624 (accessed January 2019)

Grundy, A 2014 'Nimble Innovators', Sydney Review of Books, 21 March, at https://sydneyreviewofbooks.com/nimble-innovators/ (accessed 13 March 2018)

Headon, D 1991, North of the ten commandments Hodder and Stoughton: NSW

Healy, J J 1989 Literature and the Aborigine in Australia, Brisbane: University of Queensland Press

Henningsgaard, P 2009 'Book publishing in Western Australia: A world elsewhere', Australian Studies 1,1

Indyk, I 2011 'Editorial', HEAT 24, at http://giramondopublishing.com/heat/editorial-by-ivor-indyk (accessed 3 August 2018)

Islandmagtas 2019 Jan 15 'Unfortunately Island magazine was unsuccessful in our application to the Australia Council for the Arts in the latest round of funding, along with many other literary 
organisations.' [Twitter Post], at https://twitter.com/islandmagtas/status/1084985760841756672 (accessed January 2019

Jacklin, M 2012 'Islands of multilingual literature: Community magazines and Australia's many languages' Southerly 72 (3), 129-145

James, T 1984 'From exploration to celebration: Writers and the landscape in Australia's Northern Territory', ARIEL: A Review of International English Literature, 15 (2), 55-71

Kerins, S 2015 'Indigenous communities are losing out in the development of northern Australia' The Conversation $2 \mathrm{Sept}$, at https://theconversation.com/indigenous-communities-are-losing-out-in-thedevelopment-of-northern-australia-46736 (accessed 24 Aug 2018)

Kreuger, V 2017 'How to choose the best multimedia elements for your story' Poynter Institute, at https://www.poynter.org/news/how-choose-best-multimedia-elements-your-story (accessed 29 Aug 2018)

Latz, PK 2018, Bushfires and bushtucker: Aboriginal plant use in Central Australia, Alice Springs: IAD Press

Ley, J and C Menzies-Pike (eds) 2017 The Australian Face: Essays from the Sydney Review of Books, Sydney: Giramondo

McGrath, A 2004, 'The history phoenix? Inventing a history tradition in the Northern Territory', in D Carment (ed) 2004 Northern encounters: New directions in north Australian history, Darwin: Charles Darwin University Press, 9

Mead, P 2009 'Literature, nation, region', in P Pierce (ed) The Cambridge history of Australian literature, Melbourne: Cambridge University Press, 624

Menzies-Pike, C 2017a 'Never in print', Sydney Review of Books, 12 May, at https://sydneyreviewofbooks.com/never-in-print/ (accessed 14 July 2018)

Menzies-Pike, C 2017b 'Never in print: the born-digital essay. A talk by Catriona Menzies Pike at the University of Western Sydney', at

https://www.westernsydney.edu.au/_data/assets/mp3_file/0010/1298980/Never_in_print_Catri.MP3 (accessed 14 July 2018)

Mishra, V 1988 'Aboriginal representations in Australian texts', Continuum: Journal of Media and Cultural Studies, 2 (1), 165-188

Morrison, G 2014 'In the footsteps of the ancestors: oral fixations and ethical walking on the last great songline' in S Strange, P Hetherington and J Webb (eds) Creative manoeuvres: Making, writing, being, Newcastle upon Tyne: Cambridge Scholars Publishing.

Morrison, G 2015 'Is the wealth of the North a myth?', Crikey, 3 August, at https://blogs.crikey.com.au/northern/2015/08/01/is-the-wealth-of-the-north-a-myth/ (accessed 25 February 2019)

Morrison, G 2017a Writing home: Walking, literature and belonging in Australia's red centre, Melbourne: Melbourne University Press

Morrison, G 2017b Songlines and fault lines: Epic walks of the Red Centre Melbourne: Melbourne University Press

Morrison, G 2018 'Buyout bad for the bush', Rural Weekly NT, 2 August, 5

Morrison, G 2019 'Walking, frontier and nation: Re/tracing the songlines in Central Australian literature', Journal of Intercultural Studies, 40 (1), 118-140, DOI:10.1080/07256868.2018.1552571

Moss, R 2010 The hard light of day: An artist's story of friendships in Arrernte country, St Lucia: UQP

Muscat, K (ed) 2014 Dialect, Melbourne: Global Express

Northern Territory Government 2015 'Our water future discussion paper: A Conversation with Territorians', at https://denr.nt.gov.au/_data/assets/pdf_file/0006/269304/NT-Water-Strategic-PlanDiscussion-Paper.pdf (accessed July $1 \overline{4} 2018$ ) 
Northern Territory Government 2018a 'Northern Territory economic snapshot 1 June annual change', at https://business.nt.gov.au/_data/assets/pdf_file/0010/507970/nt-economy-snapshot-201806.pdf (accessed 28 Aug 2018)

Northern Territory Government $2018 \mathrm{~b}$ 'Services to remote communities and homelands', at https://nt.gov.au/community/local-councils-remote-communities-and-homelands/services-to-remotecommunities-and-homelands (accessed 25 Aug 2018)

Northern Territory Writers' Centre 2010 This country anytime, anywhere, Alice Springs: IAD Press

Ommundsen, W and M Jacklin 2008 'Mapping literature infrastructure in Australia: A report to the Australia Council for the Arts literature board', at

https://ro.uow.edu.au/cgi/viewcontent.cgi?article=1244\&context=artspapers (accessed 25 February 2019)

Ommundsen, W 2018 'Multilingual writing in a monolingual nation: Australia's hidden literary archive', Sydney Review of Books, 24 July, at https://sydneyreviewofbooks.com/multilingual-writingmonolingual-nation/ (accessed 25 July 2018)

Park, S, C Fisher, G Fuller and J Young Lee 2018 Digital news report: Australia 2018, News and Media Research Centre, Canberra: University of Canberra 14 Jun 2018, at http://apo.org.au/node/174861 (accessed 29 Aug 2018)

Powell, A 1996 Far country: A short history of the Northern Territory, Carlton: Melbourne University Press

Pratt, M L 1991 'Arts of the contact zone', Profession, 33-40

Pratt, M L, 2008 Travel writing and transculturation, New York: Routledge, Taylor \& Francis eLibrary Edition

Regan, C and J Troy 2014 'Black words: Aboriginal and Torres Strait Islander writers and storytellers', Australian Aboriginal Studies 1, 119-124

Scaife, W, K McDonald, A Williamson, and V Mossel 2016 'Giving in Australia: Philanthropic potential beginning to be realized' in P Wiepking and F Handy (eds) The Palgrave handbook of global philanthropy, London: Palgrave Macmillan, 488-505

Schultz, J 2005 'Beyond the Brisbane line' in Up North: Myths, threats and enchantment, Griffith Review, 9, 7-10

Sefton-Rowston, A 2016 'Hope at the end of the world: Creation stories and apocalypse in Alexis Wright's Carpentaria and The Swan Book', Antipodes 30 (2), 355-368

Sefton-Rowston, A 2017 'Sovereignty as a state of craziness: Empowering female Indigenous psychologies in Australian "reconciliatory literature"', Hypatia 32, 644-659

Sefton-Rowston, A 2019 Polities and poetics: Race relations and reconciliation in Australian literature, Peter Lang: Berlin [forthcoming]

Shoemaker, A 1989 Black words, white page: Aboriginal literature 1929-1988, St Lucia: University of Queensland Press

Smith, IJ 2017 'Media and materiality: Australian literary journals in the post-digital publishing ecology', PhD thesis, at https://eprints.qut.edu.au/107725/ (accessed 25 February 2019)

Spahr, J 2018 'How to teach writing', Overland 231, Winter 3-7

Spicer, D 2016 'Arts organisations nationwide in jeopardy after Australia Council funding cuts' ABC News 12 May, at http://www.abc.net.au/news/2016-05-12/arts-organisations-nationwide-at-risk-afterfunding-cuts/740996 (accessed 29 Aug 2018).

Stinson, E 2016 'Small publishers and the emerging network of Australian literary prosumption', Australian Humanities Review 59 (April/May), at http://australianhumanitiesreview.org/2016/03/18/small-publishers-and-the-emerging-network-ofaustralian-literary-prosumption/ (accessed 18 July 2018) 
Stinson, E 2018 'Friday essay: the remarkable, prize-winning rise of our small publishers', The Conversation 4 May, at https://theconversation.com/friday-essay-the-remarkable-prize-winning-rise-ofour-small-publishers-95645 (accessed 4 July 2018)

Stratton, J 1989 'Deconstructing the Territory', Cultural Studies 3 (1), 38-57

Taylor, A and D Carson 2017 Synthesising Northern Territory population research: A report to the Northern Territory Department of the Chief Minister, Darwin: Charles Darwin University, Northern Institute

The Lifted Brow 2016 'TLB32: The ledger', The Lifted Brow Dec 9, at https://www.theliftedbrow.com/liftedbrow/tlb32-the-ledger (accessed 29 Aug 2018)

Turner, MK 2010 Iwenke Tyerrtye: What it means to be an Aboriginal person, Alice Springs: IAD Press

Turton, S 2015 'Climate: the elephant in the room for developing northern Australia', The Conversation June 22, at https://theconversation.com/climate-the-elephant-in-the-room-for-developingnorthern-australia-43528 (accessed Aug 2018)

Waller, L, K Hess and M Ricketson 2014 'Are there news gaps in rural/regional Australia? Researching media plurality beyond Finkelstein', Australian Journalism Review 36 (2), 157-169

Wright, A 2018 Tracker: Stories of Tracker Tilmouth, Artarmon: Giramondo 